\title{
Meredith Hanmer Dean of St Patrick: notes on the career of an Anglican divine in
}

\section{Elizabethan Ireland ${ }^{1}$}

In a gloss to the transcription of SP 63/141/63, the editor of the Calendar of State Papers

Ireland (henceforth, CSP Ireland) supplied a name for the otherwise anonymous Dean of St

Patrick mentioned in the 'Extract out of the Remembrances by W. Lyon, Bishop of Cork and Ross'. ${ }^{2}$ The manuscript is dated February $12,1588 / 9$. The relevant passage in the manuscript (1) and the editorial transcription (2) are printed below:

(1) the late byshop of armagh hath [spoyled] that benefis, and lovyd good chere but to well and it is sayed the dean of Saynt Patrycke can as well skyll to buy and sell matters belongynge to the church as some meaner can and as is thought not voyd from intrest upon money. (SP 63/141/63).

(2) the late John Long, Archbishop of Armagh, loved good cheer but too well; and it is said the Dean of St. Patrick's [Dr. Meredith Hanmer] can as well skill to buy and sell matters belonging to the church as some meaner can. (IV, 122, italic mine).

The description might indeed fit with Meredith Hanmer's infamous reputation in the Church of England, and also with the conjectural date of his move to Ireland, in or before $1591 .{ }^{3}$ As a vicar of St Leonard in Shoreditch in the 1580s, Hanmer had in fact allegedly converted the plates of some monuments into coins for his own use ${ }^{4}$ and was implicated in a controversy over the possession of land in the same parish, before being summoned back to England in 1593 to answer for such and further offensive practices, abuses and fraudulent dealings. ${ }^{5}$ However, the Dean of St. Patrick in 1588/89 was Richard Meredith, as also indicated in the index of the calendar volume $(\mathrm{IV}, 636)$ and in a list of the dignities of St Patrick given in SP

\footnotetext{
${ }^{1}$ The research leading to these results has received funding from the People Programme (Marie Curie Actions) of the European Union's Seventh Framework Programme (FP7/2007-2013) under REA grant agreement $n^{\circ}$ [PIEF-GA-2012-327060].

${ }^{2}$ Calendar of the state papers relating to Ireland, eds. H. C. Hamilton et al. (London, 1885), IV, 122. The mention is in a note added to the extract in the hand of Sir William Fitzwilliam, succeeding Perrot as Lord Deputy of Ireland on February 17, 1587/8.

${ }^{3}$ See Robert Dunlop and Aland Ford entries on 'Hanmer, Meredith, D.D. (1543-1604)' in the ODNB.

${ }^{4}$ John Weever, Ancient Funerall Monuments (London, 1631), 427.

${ }^{5}$ PC 2/14/227 and E 134/31Eliz/East18; PC 2/20/322.
} 
63/166/148. ${ }^{6}$ Richard Meredith held the position from 1584 to at least 1592 , while there is no evidence that Hanmer ever did. The allegations about Richard Meredith's conduct expressed in the note make sense in the light of his participation in Irish factionalism by siding with the Perrot, Lord Deputy before Fitzwilliam, in his proposals for diverting revenues of St Patrick's to the establishment of a university. ${ }^{7}$

Interestingly, the Victorian editor's slip appears also in volume III of CSP Ireland, where Meredith Hanmer is indexed as the dean of St Patrick twice (619 and 634). While these were amended in an additional list of Errata to volume III printed - remarkably enough - at the end of volume IV, the confusion between Richard Meredith and Meredith Hanmer evident in (2) must have escaped editors. From volume V of the CSP Ireland series Meredith Hanmer is restored as a vicar choral of Christ Church in Dublin, and definitively separated from Richard Meredith, Bishop of Leighlin and Dean of St Patrick.

Given the partial homonymy of the two men, it is perhaps easy to understand the editor's slip, but the match of the figure of Meredith Hanmer with the profile sketched in Fitzwilliam's note make this editorial inaccuracy particularly misleading. This is one of several inconsistencies that dot the fragmentary sources connected to Dr Meredith Hanmer, whose rising career in England seems to have been interrupted some when in the mid to late-1580s to only resume in the Church of Ireland, following a hiatus of about two years.

It is possible that the story went differently, however, since the context of Hanmer's move to Ireland is largely unknown, and there is a degree of uncertainty surrounding its chronology. Based on the cleric's earliest known appointments as archdeacon of Ross and vicar of Timoleague, Alan Ford and Robert Dunlop have both dated the move to about 1591, while

\footnotetext{
${ }^{6}$ This too is transcribed in CSP Ireland, IV, 575.

${ }^{7}$ See Helen Coburn Walshe's entry 'Meredith, Richard (d. 1597)' in the ODNB. Allegations of bribery and corruption can also be read in a memorial to Lord Burghley (CSP Ireland, IV, 139).
} 
other sources have antedated it ten years. For instance, Mahaffy maintained that he moved at the age of 38 , i.e. $1581 .^{8}$ He did not provide reference for this, but might have been informed by Wood's account in Athenae Oxonienses: 'in 1581, and 82, he took the degrees of divinity; about which time he went into Ireland', 747.

Hanmer might indeed have been in Ireland before the $1590 \mathrm{~s}$, but 1581 is difficult to accept because the move would have occurred the same year as the publication of his refutation of Campion's Letter to the Privy Council (January), followed by The Jesuit Banner [spring], his wedding in Shoreditch (June) and the appointment as vicar of the same parish (December). ${ }^{9}$ Additionally, if he was in Ireland in the 1580s, permanence must have been temporary, since evidence places him in London in $1589^{10}$ and in 1586 - when he also preached a sermon for the baptism of a Turk. ${ }^{11}$ Having arrived from Brogintyn or Pentre Pant in native North Shropshire at the border with Wales, it is apparent that the cleric was in the process of building a career in England while successfully moving closer to the centres of power.

The benefices that the cleric received once in Ireland are other details that need to be checked. A holograph letter in the State Papers dated 1602 is signed by Meredith Hanmer as warden of Youghal; however, the position is not accounted for in Alan Ford's ODNB entry, and it appears in the Dunlop's DNB profile as a rectory or wardenship. Then, the chancellorship of Ossory recorded by Alan Ford is not mentioned by Dunlop, while the

\footnotetext{
${ }^{8}$ Calendar of the State Papers relating to Ireland, of the reigns of Henry VIII., Edward VI., Mary, and Elizabeth, 1509-[1603], R. P. Mahaffy, ed. (London, 1912) XI, 59.

${ }^{9}$ An extramural suburb of London in Elizabethan times, the parish of St Leonard, Shoreditch was within the diocese of London. It is renowned for its proximity to the first Shakespearean theatre, The Curtain, built in 1576. A vivid portrait of the parish in Elizabethan London, and Meredith Hanmer as a 'vandalistic vicar' is sketched by Charles Nicholl, 'The Shoreditch Years', the Guardian (26 April 2008) commenting on the discovery of the site of the old church of St Leonard's.

${ }^{10}$ PC 2/14/227; SP 46/17/241(d); E134/31Eliz/East18.

${ }^{11}$ This was on 2 October 1586 at St Katharine by the Tower, see Meredith Hanmer, The baptizing of a Turke (London, 1586), title page.
} 
position as vicar choral of Christ Church Cathedral (Dublin) recorded by both Dunlop and the Calendar SP Ireland is not listed by Ford.

Finally, as mentioned, appearances of Hanmer(s) in the State Papers in the last quarter of the $16^{\text {th }}$ century range from implications in legal disputes to summons to answer for misdemeanours, and even appear to include implications with Catholic networks and charges of unorthodox ministering and preaching. ${ }^{12}$

In sum, the details of Hanmer's life and preferment look contradictory and much of the information that has been handed down about this figure and his dealings must in fact be reconstructed working around discrepancies, allegations, and a remarkable genealogical tree, branching out into three lines of Hanmers in the period under scrutiny. ${ }^{13}$ It is worth mentioning, then, that the inaccuracies of the Victorian editors in the CSP Ireland series seen above were printed side by side with their scrupulous annotations on the work of the cleric as an antiquarian and historian, which could enable us to reconstruct the archival vicissitudes of Hanmer's important collection of historical papers. A close analysis of these notes, documentary sources and manuscript papers will hopefully reveal us more about this elusive and fascinating figure.

ANGELA ANDREANI

University of Sussex

\footnotetext{
${ }^{12}$ Calendar of State Papers Foreign, John Butler, ed. (London, 1904), XIV; PC 2/12/170.

${ }^{13}$ On one later Hanmer see the work of Simon Healy, 'Hanmer, Sir John, 1st Bt. (c.1591-1624), of Hanmer, Flints.' In The History of Parliament: the House of Commons 1604-1629, ed. Andrew Thrush and John P. Ferris (Cambridge: Cambridge University Press, 2010); for the profile of the Hanmer family see A. H. Dodd, 'Hanmer, Family of Hanmer' in the Dictionary of Welsh Biography (http://yba.llgc.org.uk/en/index.html).
} 